\title{
Reproductive biology of dolphinfish, Coryphaena hippurus (Actinopterygii: Coryphaenidae), in Saint Peter and Saint Paul Archipelago, Brazil
}

\author{
Andrea Carla Lira Dos Santos, Isa Marielle Coutinho, Danielle De Lima Viana, \\ Mariana Gomes Do Rego, Ilka Siqueira Lima Branco, Fabio Hissa Vieira Hazin, \\ Paulo Guilherme Vasconcelos De Oliveira
}

Universidade Federal Rural de Pernambuco, Departamento de Pesca e Aquicultura, Dom Manoel de Medeiros s/n, Dois Irmãos, CEP 52171-900, Recife/PE, Brazil. E-mail: lirasantos@gmail.com

\begin{abstract}
Summary: In order to elucidate the main aspects related to dolphinfish reproduction around Saint Peter and Saint Paul Archipelago, 862 individuals caught in that area by commercial handline fishing were examined between 2007 and 2011. From those specimens, it was possible to assess the sex in 782 specimens ( 271 males and 511 females) and the levels of gonadal maturation in 536 of them (175 males and 361 females). The fork length (FL) of the examined specimens varied between 27 and $150 \mathrm{~cm}$. Sex ratio found was 1.0 male: 1.9 females, but the difference was not statistically significant in April $\left(\chi^{2}=0.08\right)$, August $\left(\chi^{2}=0.82\right)$ and October $\left(\chi^{2}=3.63\right)$. However, by size interval, sex ratio was 1.0 male: 1.0 female for FL between 120 and $130 \mathrm{~cm}$. The gonadal index showed the highest values in February for males and in April for females. Most spawningcapable specimens were found in February (males 36.4\%) and in May (females 42.2\%). The length of size-at-50\%-maturity $\left(\mathrm{L}_{50}\right)$ was estimated at $70.66 \mathrm{~cm}$ FL for males and $68.60 \mathrm{~cm}$ FL for females. The results suggest that the period of highest reproductive activity occurs between April and June.
\end{abstract}

Keywords: reproduction; sexual proportion; GI; $\mathrm{L}_{50}$; spawning season; maturation.

Biología reproductiva del dorado, Coryphaena hippurus (Actinopterygii: Coryphaenidae), en el Archipiélago de San Pedro y San Pablo, Brasil

Resumen: Con el objetivo de estudiar la reproducción del dorado capturado con línea de mano por la flota pesquera en los alrededores del Archipiélago de San Pedro y San Pablo, entre 2007 y 2011 se examinaron un total de 862 ejemplares de esta especie. Fue posible identificar el sexo de 782 de estos ejemplares (271 machos y 511 hembras), así como los estados de madurez gonadal de 536. La longitud furcal (LF) de los ejemplares examinados varió entre 27 y $150 \mathrm{~cm}$. La proporción de sexos fue de 1 macho por 1.9 hembras, aunque en abril $\left(\chi^{2}=0.08\right)$, agosto $\left(\chi^{2}=0.82\right)$ y octubre $\left(\chi^{2}=3\right.$.63) la proporción de sexos no fue significativamente diferente de 1:1, ni en los ejemplares entre 120 y $130 \mathrm{~cm} \mathrm{LF}$. El índice gonadal mostró mayores valores en febrero para machos y en abril para hembras. El mayor porcentaje de individuos maduros se observó en febrero y mayo. La talla de primera madurez sexual $\left(\mathrm{L}_{50}\right)$ se estimó en $70.66 \mathrm{~cm} \mathrm{LF}$ para machos y $68.60 \mathrm{~cm}$ LF para hembras. Los resultados sugieren que el periodo de mayor intensidad reproductiva se sitúa entre abril y junio.

Palabras clave: reproducción; proporción de sexos; IG; $\mathrm{L}_{50}$; época de puesta; madurez sexual.

Citation/Como citar este artículo: Dos Santos A.C.L., Coutinho I.M., Viana M.L., Mariana Gomes Do Rego M.G., Branco I.S.L., Hazin F.H.V., De Oliveira P.G.V. 2014. Reproductive biology of dolphinfish, Coryphaena hippurus (Actinopterygii: Coryphaenidae), in Saint Peter and Saint Paul Archipelago, Brazil. Sci. Mar. 78(3): 363-369. doi: http://dx.doi.org/10.3989/ scimar.04013.08A

Editor: E. Massutí.

Received: January 21, 2014. Accepted: June 30, 2014. Published: September 8, 2014.

Copyright: (C) 2014 CSIC. This is an open-access article distributed under the Creative Commons Attribution-Non Commercial Lisence (by-nc) Spain 3.0.

\section{INTRODUCTION}

Because of its strategic geographical position between the northern and southern hemispheres and be- tween the American and African continents, the Saint Peter and Saint Paul Archipelago (SPSPA) (Fig. 1) exerts a strong influence on the life cycle of various migratory species, for which it has great importance as 


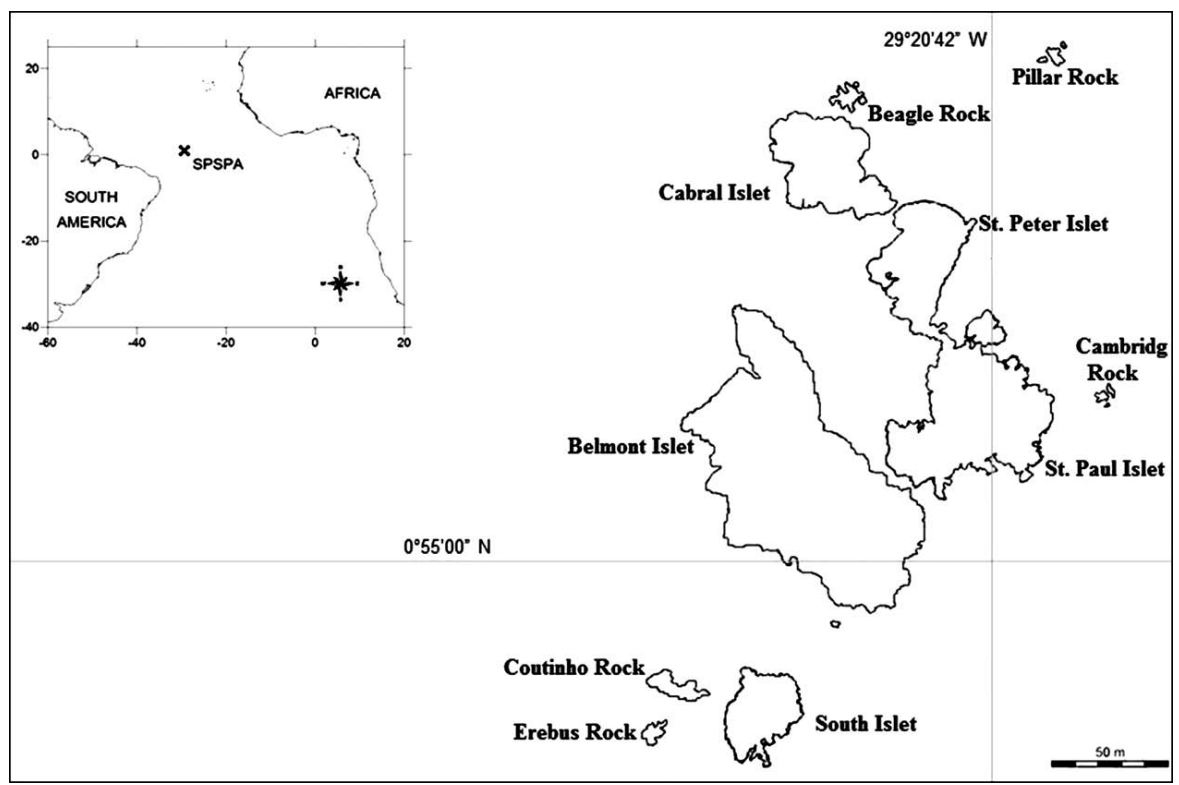

Fig. 1. - Location of the Saint Peter and Saint Paul Archipelago (Bezerra et al. 2013).

a reproduction and feeding site. In relation to meteorological condition, the climate at SPSPA is directly influenced by the Intertropical Convergence Zone, which explains why the area has one of the highest precipitation indexes in the Atlantic Ocean, particularly between December and April, and consequently a rather low sea surface salinity. In addition, the vertical temperature profile of the SPSPA is relatively stable throughout the year, with a shallow thermocline, around $25 \mathrm{~m}$, and surface temperatures ranging between $27.13^{\circ} \mathrm{C}$ and $27.92^{\circ} \mathrm{C}$ (Campos et al. 2009, Vaske-Jr 2010).

The dolphinfish, Coryphaena hippurus (Linnaeus, 1758), one of the species commonly caught in the archipelago, has a circumtropical distribution in the Atlantic, Pacific and Indian oceans (Beardsley 1967, Rose and Hassler 1968, Carpenter 2002). It is a migratory, pelagic and fast-swimming fish which is intensively caught by commercial and sport fisheries around the world (Erdman 1956, Zaneveld 1961, Sacchi et al. 1981). In the southeast Caribbean, it constitutes the largest portion of the large pelagic fish landed by commercial fisheries in both weight and revenue (Mahon et al. 1981).

Although the reproductive biology of the dolphinfish has already been studied in different places around the world (Potoschi et al. 1999, Alejo-Plata et al. 2011, Furukawa et al. 2012), in Brazil studies of the reproductive biology of the species are scarce (Souza 1998). Furthermore, the available studies show great heterogeneity in the area and the geographic and environmental conditions in which the data were obtained. It is therefore difficult to extrapolate from one region to another so studies must be carried out in geographically specific areas.

According to FAO statistics (FAO 2010), in 2008, $54339 \mathrm{t}$ of dolphinfish were caught worldwide, of which about $25 \%$ (13491 t) were caught by Ecuador, about $17 \%$ (9307 t) by Taiwan and about $16 \%(8870$ t) by Brazil.

Because the dolphinfish is a migratory species, with stocks shared and exploited by various nations, it is crucial to generate information about its biology, not only to allow a suitable assessment of their stocks but also to ensure the sustainability of its exploitation and conservation. Based on this scenario, the goal of this work was to elucidate the main aspects related to the reproduction of the dolphinfish near the SPSPA.

\section{MATERIALS AND METHODS}

The examined specimens were caught by commercial tuna fishing boats operating near the SPSPA $\left(00^{\circ} 55^{\prime} 02^{\prime \prime} \mathrm{N}, 2^{\circ} 20^{\prime} 42^{\prime} \mathrm{W}\right)$ (Fig. 1) between 2007 and 2011, using hand lines. Samples from the four years were pooled (Table 1) to construct a "year type cycle", as shown in the figures.

All specimens were identified and measured at the time of boarding, with their total length (TL) and fork length (FL) being recorded. Subsequently, the gonads were collected and preserved in formaldehyde $10 \%$ for later analysis.

In the laboratory, the gonads were weighed and measured, and the sex and stage of gonadal development were then identified by macroscopic analysis. The gonads were fixed in a solution of $10 \%$ formalin for 48 hours, suffered the first cleavage after 24 hours, were returned to the fixative solution, and then preserved in $70 \%$ alcohol. For histological analysis, the methodology described by Behmer et al. (1976) was applied. Six maturity phases were established for females: I, immature; II, developing; III, spawning-capable; IV, actively spawning; V, regressing; and VI, recovering. Five phases, adapted from Hunter et al. (1985), Murua et al. (2003) and Brown-Peterson et al. (2011), were identified for males: I, immature; II, developing; III, spawning-capable; IV, regressing; and V, recovering.

The sex ratio was estimated from the total number of females and males caught throughout the sampling period and by size interval. Statistically significant differences in the sex ratio were tested by the chi-square test $\left(\chi^{2}\right)(p<0.05)($ Snedecor and Cochran 1989). 
Table 1. - Number of dolphinfish, Coryphaena hippurus, sampled by month between 2007 and 2011 .

\begin{tabular}{lc}
\hline Month & Samples (n) \\
\hline January & 88 \\
February & 115 \\
March & 67 \\
April & 28 \\
May & 101 \\
June & 75 \\
July & 109 \\
August & 102 \\
September & 35 \\
October & 66 \\
November & 37 \\
December & 39 \\
Total & 862 \\
\hline
\end{tabular}

The gonadal index (GI) was obtained by the model proposed by Schaeffer and Orange (1956), using the following relation between the weight of the ovaries and size of the individuals: $\mathrm{GI}=\left(\mathrm{GW} 10^{5}\right) / \mathrm{FL}^{3}$, where $\mathrm{FL}$ is the fork length and GW is the gonad weight. Immature specimens were excluded from the analysis because they had not yet begun their reproductive cycle. A statistical comparison of the GI between months was done using the Kruskal-Wallis test $(\mathrm{p}<0.05)$ (Kruskal and Wallis 1952). In this study, the GI was used in place of the gonadosomatic index owing to the absence of weight scales on the boats. Nevertheless, through the determination of the months with the highest reproductive activity, the GI allows us to identify the possible spawning period. Thus, the spawning season was determined by the monthly distribution of female mean GI and monthly frequency of different maturational stages.

The average length of size-at-50\%-maturity $\left(\mathrm{L}_{50}\right)$ was obtained from the following logistic curve for both sexes, suited using the maximum likelihood approach with Statistica 7 software (Zar 2010): $Y=1 /$ $[1+\exp (a+b F L)]$, where $Y$ is the fraction of individuals who are able to reproduce (Beverton and Holt 1956), a and $b$ is coefficient of linear regression and FL is the fork length each length class.

\section{RESULTS}

Of the 862 specimens studied, $511(59.2 \%)$ were females, $271(31.5 \%)$ were males and $80(9.3 \%)$ could not have the sex identified. The FL of sampled specimens ranged between 27.0 and $150.0 \mathrm{~cm}$, with females ranging from 27.0 to $124.5 \mathrm{~cm}$, and males from 39.0 to $150.0 \mathrm{~cm}$. The highest frequency for both females and males was observed between 80 and $90 \mathrm{~cm}$ FL (Fig. 2).

The overall sex ratio was 1.0 male: 1.9 females. Females were significantly more frequent in all months, except for April $\left(\chi^{2}=0.08\right)$, August $\left(\chi^{2}=0.82\right)$ and October $\left(\chi^{2}=3.63\right)$, when females were still predominant, but the difference was not statistically significant $\left(\chi^{2}\right.$ calculated $=$ 73.66 $\left.>\chi_{\text {tabulated }}^{2}=19.68\right)$ (Table 2). Regarding the size classes, there were no statistically significant differences $\left(\chi_{\text {calculated }}^{2}=73.66>\chi_{\text {tabulated }}^{2}=19.68\right)$ (Table 3$)$, except between 70 and $110 \mathrm{~cm}$ FL. Between 120 and $130 \mathrm{~cm} \mathrm{FL}$ the sex ratio was equal to 1 male: 1 female. Between 20 and $120 \mathrm{~cm}$ FL females were more abundant and between 130 and $150 \mathrm{~cm}$ FL no females were sampled.

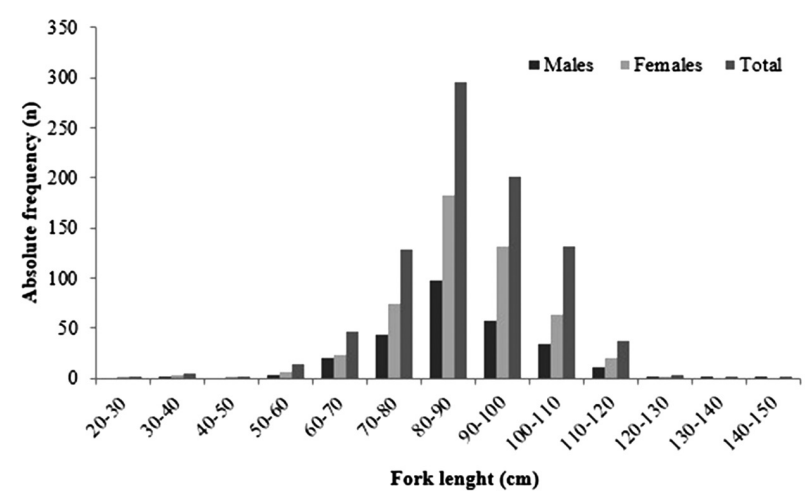

Fig. 2. - Frequency distribution of fork length of specimens of dolphinfish, Coryphaena hippurus, caught in the vicinity of the Saint Peter and Saint Paul Archipelago (n total=862, n females=511, n males=271) between 2007 and 2011.

Table 2. - Sex ratio of males and females of dolphinfish, Coryphaena hippurus, and results of the chi-square $\left(\chi^{2}\right)$.* Statistical dif-

\begin{tabular}{lcccc}
\multicolumn{5}{c}{ ference level of significance 5\% } \\
\hline & Males (n) & Females (n) & Total & $\chi^{2}$ \\
\hline Jan & 32 & 53 & 85 & $5.2^{*}$ \\
Feb & 42 & 69 & 111 & $6.6^{*}$ \\
Mar & 12 & 29 & 41 & $7.05^{*}$ \\
Apr & 6 & 7 & 13 & 0.08 \\
May & 27 & 68 & 95 & $17.7^{*}$ \\
Jun & 19 & 54 & 73 & $16.8^{*}$ \\
Jul & 41 & 62 & 103 & $4.3^{*}$ \\
Aug & 45 & 54 & 99 & 0.82 \\
Sep & 7 & 28 & 35 & $12.6^{*}$ \\
Oct & 20 & 34 & 54 & 3.63 \\
Nov & 10 & 24 & 34 & $5.8^{*}$ \\
Dec & 10 & 29 & 39 & $9.26^{*}$ \\
Total & 271 & 511 & 782 & $73.66^{*}$ \\
\hline
\end{tabular}

Table 3. - Sex ratio by size interval of males and females of dolphinfish, Coryphaena hippurus, and results of the chi-square $\left(\chi^{2}\right)$.* Statistical difference level of significance 5\%

\begin{tabular}{lcccc}
\hline Size interval (cm FL) & $\begin{array}{c}\text { Males } \\
(\mathrm{n})\end{array}$ & $\begin{array}{c}\text { Females } \\
(\mathrm{n})\end{array}$ & Total & $\chi^{2}$ \\
\hline $20-30$ & 0 & 1 & 1 & 1 \\
$30-40$ & 2 & 3 & 5 & 0.2 \\
$40-50$ & 0 & 2 & 2 & 2 \\
$50-60$ & 3 & 7 & 15 & 1.6 \\
$60-70$ & 20 & 24 & 47 & 0.4 \\
$70-80$ & 43 & 75 & 128 & $8.7^{*}$ \\
$80-90$ & 97 & 183 & 295 & $26.4^{*}$ \\
$90-100$ & 57 & 131 & 201 & $29.1^{*}$ \\
$100-110$ & 34 & 63 & 131 & $8.7^{*}$ \\
$110-120$ & 11 & 20 & 38 & 2.6 \\
$120-130$ & 2 & 2 & 4 & 0 \\
$130-140$ & 1 & 0 & 2 & 1 \\
$140-150$ & 1 & 0 & 1 & 1 \\
Total & 271 & 511 & 870 & $73.66^{*}$ \\
\hline
\end{tabular}

According to the histological analysis of the testes, of the 175 males examined, 16 were immature (39.0 to 71.0 $\mathrm{cm} \mathrm{FL),} 56$ were developing ( 72.0 to $124.0 \mathrm{~cm} \mathrm{FL),} 11$ were spawning- capable ( 81.0 to $150.0 \mathrm{~cm} \mathrm{FL),} 8$ were regressing (91.0 to $108.0 \mathrm{~cm} \mathrm{FL)} \mathrm{and} 84$ were recovering (70.0 to $108.0 \mathrm{~cm}$ FL). The frequency distribution of monthly stages of gonadal maturation indicates a higher frequency of immature males in July (43.7\%), developing in January (21.4\%), spawning-capable in February (36.4\%) and recovering in July (27.4\%) (Fig. 3).

Of the 361 females examined, according to the histological analyses, 42 were immature (27.0 to 72.0 $\mathrm{cm}$ FL), 140 were developing (43.0 to $115.0 \mathrm{~cm} \mathrm{FL),}$ 


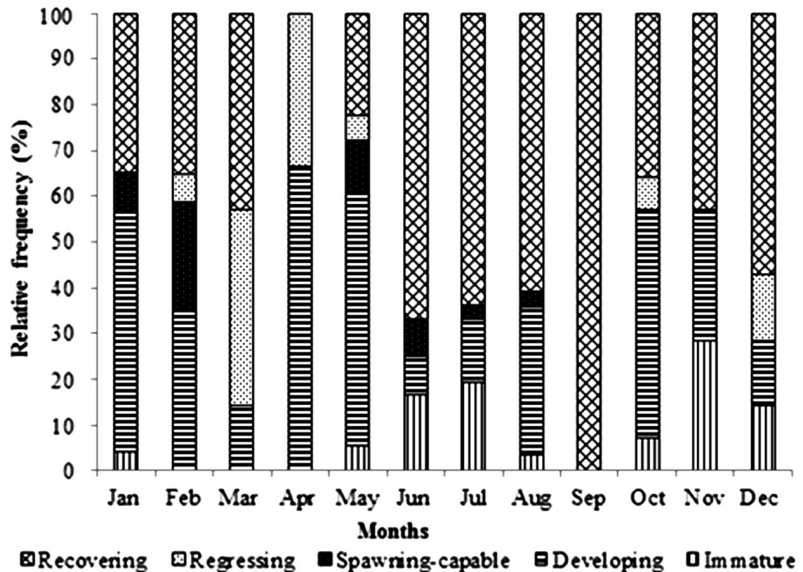

Fig. 3. - Relative frequency of maturity stages of male dolphinfish, Coryphaena hippurus $(\mathrm{n}=175)$ caught in the vicinity of the Saint

Peter and Saint Paul Archipelago between 2007 and 2011.

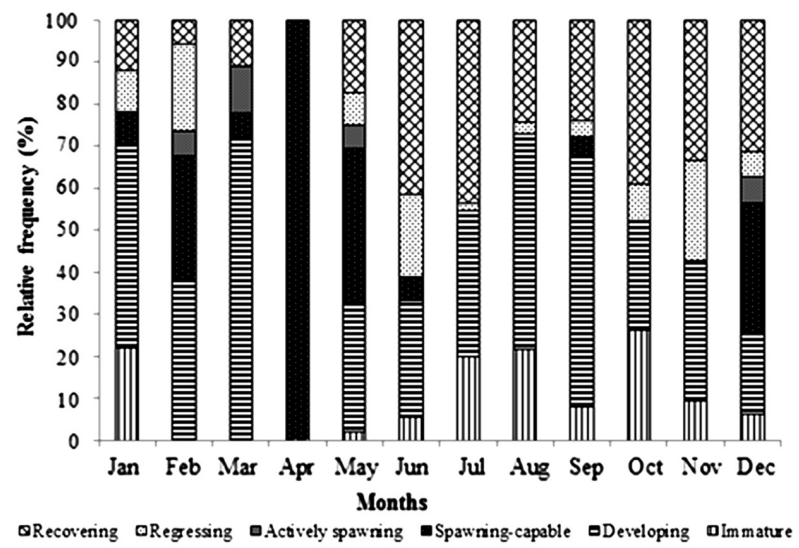

Fig. 4. - Relative frequency of maturity stages of female dolphinfish, Coryphaena hippurus $(\mathrm{n}=361)$, caught in the vicinity of the Saint Peter and Saint Paul Archipelago between 2007 and 2011 (the bars represent the standard deviation).
45 were spawning-capable $(64.0$ to $124.5 \mathrm{~cm}), 8$ were actively spawning $(75.0$ to $117.0 \mathrm{~cm}), 33$ were regressing $(72.0$ to $108.0 \mathrm{~cm})$ and 93 were recovering $(63.0$ to $106.0 \mathrm{~cm} \mathrm{FL)}$. There was a higher frequency of immature females in July (26.2\%), developing in January (14.2\%), July and August (13.5\%), spawning-capable in May (42.2\%), actively spawning also in May $(37.5 \%)$, regressing in February and June $(21.2 \%)$, and recovering in June (16.13\%) and July (25.8\%) (Fig. $4)$. The gonad maturation phases for both males and females are described in Tables 4 and 5, respectively.

The weight of male gonads ranged from 0.49 to $90.00 \mathrm{~g}$, with the monthly mean GI ranging from 0.58 to 3.73 , with a peak in February (Fig. 5). For females, the gonad weight ranged from 0.77 to $597.20 \mathrm{~g}$, with the monthly mean GI ranging from 3.24 to 34.90 , with a peak in April, suggesting that spawning occurs between April and June (Fig. 6). The monthly mean GI for both males and females showed statistically signifi-

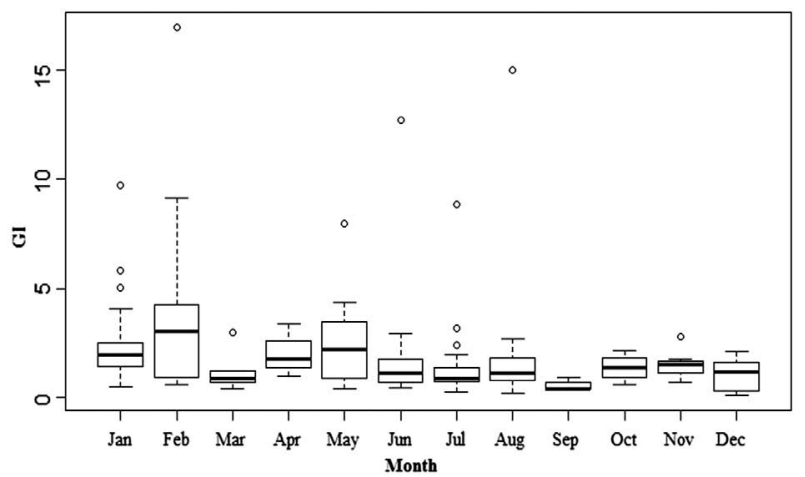

Fig. 5. - Monthly mean gonadal index (GI) of male dolphinfish, Coryphaena hippurus $(\mathrm{n}=175)$, caught in the vicinity of the Saint Peter and Saint Paul Archipelago between 2007 and 2011 (the bars represent the standard deviation).

Table 4. - Macroscopic and microscopic characterization of the maturity phases of the testes of Coryphaena hippurus in the Saint Peter and Saint Paul Archipelago, adapted from Hunter et al. (1985), Murua et al. (2003) and Brown-Peterson et al. (2011).

\begin{tabular}{|c|c|c|}
\hline Stage & Macroscopic characteristics & Microscopic characteristics \\
\hline I. Immature & $\begin{array}{l}\text { Small and threadlike testes often clear (translucent) with } \\
\text { a light yellow colour. Difficult for sex distinction. }\end{array}$ & $\begin{array}{l}\text { Compact cell form. Displays only primary } \\
\text { spermatogonia; the lumen is not divided into lobes. }\end{array}$ \\
\hline II. Developing & $\begin{array}{l}\text { Testes with yellow-white colour (translucent to } \\
\text { opaque with a small width and reduced thickness, but } \\
\text { measurable); due to its reduced thickness, there is an } \\
\text { inaccuracy in the observation of the ventral streaks and } \\
\text { the cross section median. At the end of this phase, a few } \\
\text { sperm may be present in the sperm channel. }\end{array}$ & $\begin{array}{l}\text { Spermatocytes present throughout the lobules. May } \\
\text { show secondary spermatogonia, primary and secondary } \\
\text { spermatocytes, spermatids and spermatozoa. No sperm } \\
\text { is present in the lumen of the lobules or sperm ducts. } \\
\text { Germinal epithelium is continuous throughout the testes. }\end{array}$ \\
\hline
\end{tabular}

$\begin{array}{ll}\text { III. Spawning- } & \text { Large and firm testes, white to pink coloration, } \\ \text { capable } & \text { sometimes with reddish spots with increased } \\ & \text { vascularization; tubular form; ventral streaks usually } \\ & \text { present (in the form of lobes); outer membrane is easily } \\ & \text { ruptured when handled, ripping by its own weight. } \\ & \text { Abundant semen throughout the testis. }\end{array}$

IV. Regressing Small and flaccid testicles, no semen released with pressure. Has residual spermatozoa in the lumen of the lobules and the spermatic duct.

V. Recovering
Small testes, often threadlike. No spermatocytes are present. The lumen is not divided into lobes.
All spermatogenesis stages may be present.

Spermatocysts are present throughout the testis, active spermatogenesis. Germinal epithelium may be continuous or discontinuous.

Spermatocysts are widely scattered near the periphery containing secondary spermatocytes, spermatids and spermatozoa. Little or no active spermatogenesis. Spermatogonial proliferation and regeneration of common germinal epithelium at the periphery of the testes (cell disorganization present).

Proliferation of spermatogonia throughout testis. Continuous germinal epithelium throughout testis, different from the immature testis due to the testicle wall thickness and evident spacing, indicating previous reproductions. 
Table 5. - Macroscopic and microscopic characterization of the maturity phases of the ovaries of Coryphaena hippurus in the Saint Peter and Saint Paul Archipelago, adapted from Hunter et al. (1985), Murua et al. (2003) and Brown-Peterson et al. (2011).

\begin{tabular}{|c|c|c|}
\hline Stage & Macroscopic Characteristics & Microscopic Characteristics \\
\hline I. Immature & $\begin{array}{l}\text { Small and threadlike ovaries, often translucent, } \\
\text { yellowish colour, without opaque oocytes. Ovary has a } \\
\text { thin wall on which blood vessels are indistinct, making } \\
\text { sex distinction difficult. }\end{array}$ & $\begin{array}{l}\text { Only oogonia and oocytes in primary growth are } \\
\text { present. Atresia is not present. Thin ovarian wall and } \\
\text { small space between oocytes, oocytes demonstrate a } \\
\text { cluster conformation with visible cellular organization. }\end{array}$ \\
\hline II. Developing & $\begin{array}{l}\text { Medium sized ovaries, orange colour, still with no } \\
\text { noticeable opaque oocytes, and blood vessels are } \\
\text { becoming more distinct. }\end{array}$ & $\begin{array}{l}\text { Beginning of vitellogenesis; oocytes are in primary } \\
\text { growth, cortical alveoli and vitellogenesis } 1 \text { and } 2 \text {. No } \\
\text { advanced stage of vitellogenesis is present. }\end{array}$ \\
\hline III. Spawning-capable & $\begin{array}{l}\text { Large ovaries, bright yellow colouration, prominent } \\
\text { blood vessels. Individual oocytes are macroscopically } \\
\text { visible. }\end{array}$ & $\begin{array}{l}\text { Oocytes present in vitellogenesis } 3 \text {. A few hydrated } \\
\text { oocytes may be present. Early stages of oocyte } \\
\text { maturation are present. In some oocytes, the yolk } \\
\text { appears dense with multiple transparent lipid bodies } \\
\text { around the nucleus. }\end{array}$ \\
\hline $\begin{array}{l}\text { IV. Actively } \\
\text { spawning }\end{array}$ & $\begin{array}{l}\text { Translucent oocytes, which may or may not flow when } \\
\text { pressure is applied. Hydrated oocytes are larger than } \\
\text { the opaque oocytes. The gonad becomes delicate to the } \\
\text { touch and may break. }\end{array}$ & $\begin{array}{l}\text { Presence of oocytes with germinal vesicle migration. } \\
\text { Hydrated oocytes (translucent) in large quantities and } \\
\text { with few post-ovulatory follicles (POFs). }\end{array}$ \\
\hline V. Regressing & $\begin{array}{l}\text { Very flaccid ovary, appearing haemorrhagic with } \\
\text { orange colour and purple spots. Occasionally with a few } \\
\text { remaining translucent oocytes. }\end{array}$ & $\begin{array}{l}\text { Atresia (at any stage) and POFs are present. Presence of } \\
\text { cortical oocyte and/or vitellogenesis } 1 \text { and } 2 \text {. Cellular } \\
\text { disorganization is noted. }\end{array}$ \\
\hline VI. Recovering & $\begin{array}{l}\text { Small ovaries, orange-dark brown coloration, opaque } \\
\text { oocytes are not present; contains a thicker membrane } \\
\text { than the immature fish. Displays reduced blood vessels. }\end{array}$ & $\begin{array}{l}\text { Only oogonia and primary growth oocytes are present. } \\
\text { Muscle bundles, dilated blood vessels, thick ovary wall, } \\
\text { has degenerating POFs and previous atresia (gamma/ } \\
\text { delta). }\end{array}$ \\
\hline
\end{tabular}

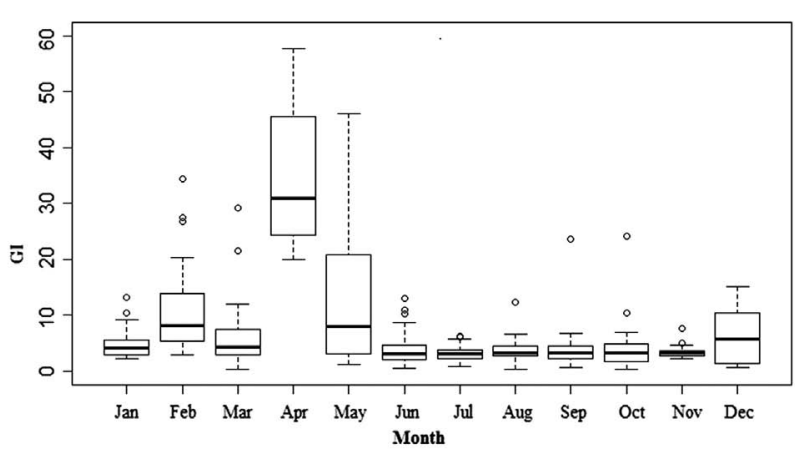

Fig. 6. - Monthly mean gonadal index (GI) of female dolphinfish, Coryphaena hippurus $(\mathrm{n}=361)$, caught in the vicinity of the Saint Peter and Saint Paul Archipelago between 2007 and 2011 (the bars represent the standard deviation).

cant differences (Kruskal-Wallis, $\mathrm{p}_{\text {males }}=0.0008072$, $\left.\mathrm{p}_{\text {females }}=1.496 \mathrm{e}-11\right)$.

The size-at-50\%-maturity $\left(\mathrm{L}_{50}\right)$ estimated for males and females (Fig. 7) was equal to 70.66 and $68.60 \mathrm{~cm}$ FL, respectively. Of the 271 males examined only 26 $(9.6 \%)$ had an FL smaller than the size at first maturity, whereas of the 511 females only $29(5.7 \%)$ exhibited an FL lower than that. These results indicate a predominance of adults in the sampled population.

\section{DISCUSSION}

The sex ratio found in this study (1.0 male: $1.9 \mathrm{fe}-$ males) was very close to that found by Potoschi et al. (1999) in the western and Central Mediterranean, equal to 1 male: 2 females for juvenile samples and 1 male: 1 female for adult specimens.

Castro et al. (1999) obtained in the Canary Islands a sex ratio equal to 1.0 male:1.4 females for dolphinfish, with females predominating in size intervals lower than $85 \mathrm{~cm}$ FL, while in size intervals larger than 90 $\mathrm{cm}$ FL the males predominated. However, in a similar study conducted for Coryphaena equiselis the authors

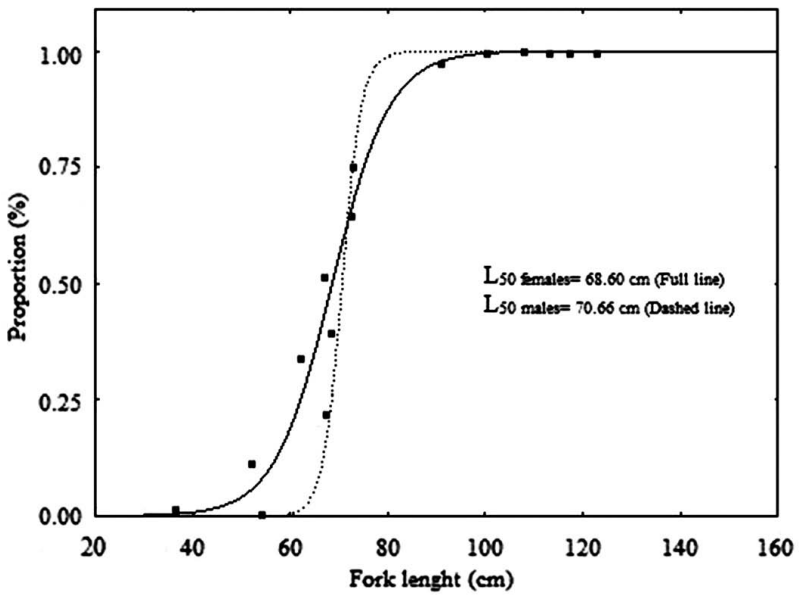

Fig. 7. - Length at first sexual maturity $\mathrm{L}_{50}$ for males $(n=175)$ and females $(\mathrm{n}=361)$ of Coryphaena hippurus caught in the vicinity of the Saint Peter and Saint Paul Archipelago between 2007 and 2011.

concluded that, although the sex ratio was also 1.0 male: 1.4 females, for both the adults and the period in which the highest values of GSI were shown, the sex ratio found was 1 male: 1 female. The sample size (150 Coryphaena equiselis and 36 Coryphaena hippurus), however, probably influenced these results.

On the other hand, Lasso and Zapata (1999) found a sex ratio very close to 1:1 (1.0 male:0.96 females) on the coast of Colombia and Panama; the males were predominant from June to December and females from January to May. A fairly equal amount of males and females was found in January.

Similarly, Massuttí and Morales-Nin (1997) found a sex ratio equal to 1 male: 1 female at the island of Majorca, with no significant difference. The distribution of sexes by size interval, however, showed a significant predominance of females in specimens smaller than 25 $\mathrm{cm}$ FL and a high proportion of males for individuals $\geq 150 \mathrm{~cm}$ FL, though this interval was not significantly 
Table 6. - Size at first sexual maturity $\left(\mathrm{L}_{50}\right)$ for males and females of dolphinfish, Coryphaena hippurus, reported in the literature.

\begin{tabular}{lcccc}
\hline Author & Year & Place & $\mathrm{L}_{50}$ Males & $\mathrm{L}_{50}$ Females \\
\hline Campos et al. & 1993 & Costa Rica & $130 \mathrm{~cm} \mathrm{TL}$ & $130 \mathrm{~cm} \mathrm{TL}$ \\
Massuttí and Morales-Nin & 1997 & Western Mediterranean & $61.8 \mathrm{~cm} \mathrm{FL}$ & $54.5 \mathrm{~cm} \mathrm{FL}$ \\
Wu et al. & 2001 & Taiwan & $51 \mathrm{~cm} \mathrm{FL}$ & $51 \mathrm{~cm} \mathrm{FL}$ \\
Schwenke and Buckel & 2008 & North Carolina & $47.6 \mathrm{~cm} \mathrm{FL}$ & $45.8 \mathrm{~cm} \mathrm{FL}$ \\
Alejo-Plata et al. & 2011 & Gulf of Tehuantepec, Mexico & $50.57 \mathrm{~cm} \mathrm{FL}$ & $48.38 \mathrm{~cm} \mathrm{FL}$ \\
Zúñiga-Flores et al. & 2011 & Gulf of California, Mexico & $80 \mathrm{~cm} \mathrm{FL}$ & $80 \mathrm{~cm} \mathrm{FL}$ \\
\hline
\end{tabular}

different from 1:1 because of the small number of specimens sampled ( 5 males and 2 females).

Zúñiga-Flores et al. (2011) found a sex ratio equal to 1 male: 1 female in the Gulf of California, with no significant difference. The proportion of females, however, was greater for FL below $90.0 \mathrm{~cm}$, while the opposite was observed for larger sizes.

Campos et al. (1993) reported a sex ratio off Costa Rica equal to 2 males: 1 female, which, according to them, provided evidence of a separation between adult and young males, with the latter staying nearer the coast.

Potoschi et al. (1999) obtained juvenile samples (between 20 and $60 \mathrm{~cm}$ FL) from a commercial fleet using surrounding-nets and adults samples as bycatch from a commercial fleet using longline, drifting-net and harpoon. Massuttí and Morales-Nin (1997) obtained the samples from commercial catches of two different fisheries: juveniles by small-scale fishery using surrounding net and adults by Xiphias gladius longline fishery. Zúñiga-Flores et al. (2011) obtained their samples from a sportfishing fleet and an artisanal fishery, using trolling surface baits and artificial lures and small longlines, respectively. Lasso and Zapata (1999) obtained their samples from an industrial fleet targeting sharks by surface nets. Although various fishing methods were used to obtain the specimens of the cited authors, all of our specimens were captured using a single method (hand line). The results found in this study suggest that the sex ratio might be influenced by both size and sexual stage, as proposed by Potoschi et al. (1999), because for individuals between 120 and $130 \mathrm{~cm}$ FL the sex ratio was 1 male: 1 female in the SPSPA.

Regarding the gonad maturation phases, the microscopic descriptions shown in this study are similar to the ones found by Alejo-Plata et al. (2011) and ZúñigaFlores et al. (2011) for females, in stages III (spawningcapable), IV (actively spawning) and V n(regressing). Likewise, Zúñiga-Flores et al. (2011) showed a similar microscopic description for males in stages II (developing) and III (spawning-capable).

The highest monthly mean values of GI coincided with those of other species in the SPSPA, such as wahoo (Viana et al. 2008), rainbow runner (Pinheiro et al. 2010) and blackfin tuna (Bezerra et al. 2013), which also exhibit a period of increased reproductive activity in the first half of the year, coinciding with the presence of flying fish at the study site.

Castro et al. (1999) reported values of gonadosomatic index (GSI) with a peak in June for both sexes in the Canary Islands, coinciding with the summer in that region. Schwenke and Buckel (2008) reported that the highest values of GSI occurred in May for males and females in North Carolina. Similarly, Furukawa et al. (2012) found the highest values of GSI in May for males and in July for females in the northern East China Sea. Campos et al. (1993) observed peaks of GSI in April, August and September in Costa Rica. Potoschi et al. (1999), working with individuals from the Mediterranean Sea, found the highest values of GSI between June and September, when all the individuals sampled were mature, with a peak in July. Wu et al. (2001) found peaks of GSI for males and females in February and March in Taiwan, but suggested that the dolphinfish has a long breeding season, during which it spawns almost continuously. Similarly, Alejo-Plata et al. (2011) observed a long spawning season for the dolphinfish off Mexico, with several peaks of GSI and the top two happening in September-November and between February and April. Massuttí and MoralesNin (1995), based on the GSI, reported a spawning season from June to August for females, and from June to September for males at the island of Majorca. Zúñiga-Flores et al. (2011) concluded that the period of greatest reproductive activity in the Gulf of California coincided with the highest abundance, which, in turn, coincided with the increase in sea surface temperature. Most of these results therefore indicate that, as in the SPSPA, the greatest reproductive activity for the dolphinfish occurs in the warmest months of the summer in various regions of the world.

The spawning season for dolphinfish were defined and identified by a combination of several techniques, including sex ratio, GI and frequency distribution of monthly stages of gonadal maturation. The period of greatest reproductive activity of the dolphinfish in the SPSPA occurs just after the peak of the spawning of flying fish (between December and March), one of its preferred prey, when it becomes particularly abundant at the site, probably providing the energy the dolphinfish requires to grow and mature its gonads. This event seems to influence the migratory cycle and reproduction not only of dolphinfish but also of other species that feed on the flying fish (Hazin 2009). This would explain the decrease in reproductive activity of the species in the second half of the year, coinciding with a lower food availability and consequently greater difficulty for the maturation of the gonads. If no abrupt changes occur in the local weather throughout the year, the reproduction in the SPSPA is probably conditioned by the trophic factor.

The length size-at-50\%-maturity $\left(\mathrm{L}_{50}\right)$ found for both males and females (70.66 and $68.60 \mathrm{~cm}$ FL, respectively) is within the range reported in the literature (Table 6 ). The fact that only $7 \%$ of males and females sampled were below the $\mathrm{L}_{50}$ is a positive aspect for the sustainability of the fishery conducted in this region. 


\section{REFERENCES}

Alejo-Plata C., Díaz-Jaimes P., Salgado-Ugarte I.H. 2011. Sex ratios, size at sexual maturity and spawning seasonality of dolphinfish Coryphaena hippurus captured in the Gulf of Tehuantepec, Mexico. Fish. Res. 110: 207-216. http://dx.doi.org/10.1016/j.fishres.2011.04.008

Beardsley G.L.Jr. 1967. Age, growth, and reproduction of the dolphin, Coryphaena hippurus, in the Straits of Florida. Copeia 2: 441-451. http://dx.doi.org/10.2307/1442132

Behmer O.A., Tolosa E.M.C., Neto A.G.F. 1976. Manual de Técnicas para Histologia Normal e Patológica. EDART, 239 pp.

Beverton R.J.H., Holt S.J. 1956. A review of methods for estimating mortality rates in fish populations, with special references to sources of bias in catch sampling. Rapp. P.-V. Reun. Cons. Perm. Int. Explor. Mer. 140: 67-83.

Bezerra N.P.A., Fernandes C.A.F., Albuquerque F.V., et al. 2013. Reproduction of Blackfin tuna Thunnus atlanticus (Perciformes: Scombridae) in Saint Peter and Saint Paul Archipelago, Equatorial Atlantic, Brazil. Rev. Biol. Trop. 61(3): 1327-1339.

Brown-Peterson N.J., Wyanski D.M., Saborido-Rey F., et al. 2011. A Standardized Terminology for Describing Reproductive Development in Fishes. Mar. Coast. Fish. Dyn. Manage. Ecosyst. Sci. 3:52-70. http://dx.doi.org/10.1080/19425120.2011.555724

Campos J.A., Segura A., Lizano O., et al. 1993. Ecología básica de Coryphaena hippurus (Pisces: Coryphaenidae) y abundancia de otros grandes pelágicos en el Pacífico de Costa Rica. Rev. Biol. Trop. 41(3): 783-790.

Campos T.F.C., Neto J.V., Srivastava N.K., et al. 2009. Arquipélago de São Pedro e São Paulo - Soerguimento tectônico de rochas infracrustais no Oceano Atlântico. In: Winge M. et al. (eds) Sítios Geológicos e Paleontológicos do Brasil. Brasília: CPRM, 515 pp.

Carpenter K.E. (ed.) 2002. The living marine resources of the Western Central Atlantic. Volume 3: Bony fishes part 2 (Opistognathidae to Molidae), sea turtles and marine mammals. FAO Species Identification Guide for Fishery Purposes and American Society of Ichthyologists and Herpetologists Special Publication, Rome, FAO Fish. 5: 1375-2127.

Castro J.J., Santiago J.A., Hernandez-Garcia V., et al. 1999. Growth and reproduction of the dolphinfish (Coryphaena equiselis and Coryphaena hippurus) in the Canary Islands, Central-East Atlantic (preliminary results) Sci. Mar. 63(3-4): 317-325.

Erdman D.S. 1956. Recent fish records from Puerto Rico. B. Mar. Sci. 6: 315-348

FAO. 2010. Fishery and Aquaculture Statistics - Capture Production. FAO Yearb Fish Stat Catches Land. 522 pp.

Furukawa S., Ohshimo S., Tomoe S., et al. 2012. Age, growth, and reproductive characteristics of dolphinfish Coryphaena hippurus in the waters off West Kyushu, northern East China Sea. Fish. Sci. 78: 1153-1162. http://dx.doi.org/10.1007/s12562-012-0557-6

Hazin F.H.V. 2009. 10 Anos da Estação Científica do Arquipélago de São Pedro e São Paulo: o que já foi aprendido e o que falta por aprender. In: Viana D.L., Hazin F.H.V., Souza M.A.C. (eds), Arquipélago de São Pedro e São Paulo: 10 anos de Estação Científica. Brasília, SECIRM v. 3000. 348 pp.

Hunter J.R., Lo N.C., Leong R.J. 1985. Batch fecundity in multiple spawning fishes. In: Lasker, R. (ed.), An Egg Production Method for Estimating Spawning Biomass of Pelagic Fish: Application to the Northern Anchovy, Engraulis mordax. US Natl. Mar. Fish. Serv., NOAA Tech. Rep. 36: 67-78.

Kruskal W.H., Wallis W.A. 1952. Use of ranks in one-criterion variance analysis. J. Amer. Statist. Assoc. 47: 583-621. http://dx.doi.org/10.1080/01621459.1952.10483441

Lasso J., Zapata L. 1999. Fisheries and biology of Coryphaena hippurus (Pisces: Coryphaenidae) in the Pacific coast of Colombia and Panama. Sci. Mar. 63(3-4): 387-399.

Linnaeus C. 1758. Systema Naturae. Ed. 10. Facsimile. Natural History Museum, England. 824 pp.

Mahon R., Hunte W., Oxenford H., et al. 1981. Seasonality in the commercial marine fisheries of Barbados. Proc. Gulf Caribb. Fish. Inst. 34: 28-37.

Massuttí E., Morales-Nin B. 1995. Seasonality and reproduction of dolphin-fish Coryphaena hippurus in the Western Mediterranean. Sci. Mar. 59(3-4): 357-364

Massuttí E., Morales-Nin B. 1997. Reproductive biology of dolphin-fish (Coryphaena hippurus L.) off the island of Majorca (western Mediterranean). Fish. Res. 30: 57-65. http://dx.doi.org/10.1016/S0165-7836(96)00562-0

Murua H., Kraus G., Saborido-Rey F., et al. 2003. Procedures to estimate fecundity of marine fish species in relation to their reproductive strategy. J. Northwest Atl. Fish. Sic. 33: 33-54. http://dx.doi.org/10.2960/J.v33.a3

Pinheiro P.B., Hazin F.H.V., Travassos P., et al. 2010. The reproductive biology of the rainbow runner, Elagatis bipinnulata (Quoy and Gaimard, 1825) caught in the São Pedro and São Paulo Archipelago. Braz. J. Biol. 71(1): 99-106. http://dx.doi.org/10.1590/S1519-69842011000100015

Potoschi A., Renones O., Cannizzaro L. 1999. Sexual development, maturity and reproduction of dolphinfish (Coryphaena hippurus) in the western and central Mediterranean. Sci. Mar. 63(3-4): 367-372.

Rose C.D., Hassler W.W. 1968. Age and growth of the dolphin, Coryphaena hippurus (Linnaeus), in North Carolina Waters. Trans. Am. Fish Soc. 97: 271-276.

http://dx.doi.org/10.1577/1548-8659(1968)97[271:AAGOTD] 2.0.CO;2

Sacchi J., Lagin A, Langlais, C. 1981. La pêche des espèces pélagiques aux Antilles Français. Etat actuel et perspective de développement. Bull. Inst. Pech. Maroc. 312: 1-15.

Schaeffer M.B., Orange C.J. 1956. Studies of the sexual development and spawning of yellowfin tuna (Neothunnus macropterus) and skipjack (Katsuwonus pelamis) in the three areas of the Eastern Pacific Ocean, by examination of gonads. Inter-Am. Trop. Tuna Comm. Spec. Rep. 1(6): 281-302.

Schwenke K., Buckel J.A. 2008. Age, growth and reproduction of dolphinfish (Coryphaena hippurus) caught off the coast of North Carolina. Fish. Bull. 1: 82-92.

Snedecor G.W., Cochran W.G. 1989. Statistical Methods. Iowa State University, Press Ames Iowa.

Souza R.S. 1998. Distribuição, abundância e reprodução do dourado, Coryphaena hippurus (Linnaeus, 1758), na região Nordeste do Brasil. M. Sc. thesis, Uni. Federal de Pernambuco, 73 pp.

Vaske-Jr T. 2010. Arquipélago de São Pedro e São Paulo: histórico e recursos naturais/ Teodoro Vaske Júnior et al. - Fortaleza: NAVE/ LABOMAR UFC, 242 pp.

Viana D.L., Hazin F.H.V., Nunes D.M., et al. 2008. Wahoo Acanthocybium solandri fishery in the vicinity of Saint Peter and Saint Paul Archipelago, Brazil, from 1998 to 2006. Collective Volume of Scientific Papers. International Commission for the Conservation of Atlantic Tunas.

Wu C.C., Su W.C., Kawasaki T. 2001. Reproductive biology of the dolphin fish Coryphaena hippurus on the east coast of Taiwan. Fish. Sci. 67: 784-793. http://dx.doi.org/10.1046/j.1444-2906.2001.00324.x

Zaneveld J.S. 1961. The fishery resources and the fishery industries of the Netherlands Antilles. Proc. Gulf Caribb. Fish. Inst. 14: 137-171.

Zar J. 2010. Biostatistical analysis. Prentice-Hall, Englewood Cliffs, New Jersey, USA

Zúñiga-Flores M.S., Ortega-García S., Rodríguez-Jaramillo M.C., et al. 2011. Reproductive dynamics of the common dolphinfish Coryphaena hippurus in the southern Gulf of California. Mar. Biol. Res. 7(7): 677-689. http://dx.doi.org/10.1080/17451000.2011.554558 